\title{
LETTER
}

\section{Increased frequency of the homozygous II ACE genotype in Italian Olympic endurance athletes}

European Journal of Human Genetics (2002) 10, 576-577. doi:10.1038/sj.ejhg.5200852

Angiotensin-converting enzyme (ACE, EC 3.4.15.1) plays an important role in the circulatory homoeostasis by generating the potent vasoconstrictor angiotensin II and degrading the vasodilator bradykinin. ${ }^{1}$ An insertion polymorphism in the gene coding for $\mathrm{ACE}^{2}$ has been reported to be associated with decreased ACE activity ${ }^{3}$ as well as with improved physical performance. ${ }^{4}$ The insertion (I) allele turned out to be over-represented among high-altitude mountaineers ${ }^{4}$ and carriership of at least one I allele was associated with improved endurance among males recruited in the UK army. ${ }^{4}$ Among elite endurance athletes, a significantly higher frequency of the I allele was reported in 64 Australian rowers, ${ }^{5} 79$ British Olympic-standard runners selected as potential Olympic competitors ${ }^{6}$ and 60 Spanish athletes, ${ }^{7}$ as compared with controls. Conversely, an excess of the deletion (D) allele has been reported among elite athletes competing in more power-oriented sports such as short distance swimming ${ }^{6,8}$ and sprinting. ${ }^{6}$

Therefore, recruitment of athletes from mixed disciplines may result in lack of association between the ACE polymorphism and physical performance, ${ }^{9,10}$ as recently pointed out by Nazarov et al. ${ }^{11}$ In that study, the ACE genotype/allele distribution of all athletes was not different from that of controls, but an excess of the D allele was observed among sprinters (short distance athletes) and an excess of the I allele among athletes competing over 1 to $20 \mathrm{~min}$ (middle distance athletes). ${ }^{11}$

We have investigated the distribution of ACE genotypes in 126 Italian athletes (101 males and 25 females aged between 18 and 35 years) designated as 'candidate Olympic athletes' by their own Sport Federations. The ACE genotype frequency distribution of all athletes did not differ from that of 152 healthy Italian subjects aged between 16 and 40 years. The study group included 71 'aerobic' athletes (26 road cyclists, 17 track and field endurance athletes, 28 cross-country skiers), who can be classified as 'long distance athletes',11 and 55 'anaerobic' flat-water kayak athletes (racing times between 30 and 210 s). Genotype and allele frequencies of aerobic and anaerobic athletes did not differ from those of the control group. Comparison between the athlete groups showed a significant difference for genotypes $(P=0.03)$ but not for alleles (Table 1$)$.

Among the 126 athletes we further selected an elite group of 52 (33 aerobic and 19 anaerobic), based on actual participation in the Olympic Games (14 Olympic Medallists, six of which won the gold medal; nine World Champions) and top aerobic performance $\left(\mathrm{VO}_{2} \max\right.$ values between 65 and $80 \mathrm{ml} / \mathrm{Kg}$ for aerobic athletes, and between 40 and 55 for anaerobic athletes). The selection was made by a person $(\mathrm{GM})$ that was unaware of the athletes' ACE

Table 1 ACE genotypes in Italian athletes

\begin{tabular}{|c|c|c|c|c|c|c|c|}
\hline \multirow[b]{2}{*}{ Aerobic athletes } & \multirow[b]{2}{*}{$n$} & \multicolumn{2}{|c|}{$D D$} & \multicolumn{2}{|c|}{ ID } & \multicolumn{2}{|c|}{ II } \\
\hline & & $n$ & $\%$ & $n$ & $\%$ & $n$ & $\%$ \\
\hline All aerobic athletes & 71 & $28^{\#}$ & 39.4 & $28^{\#}$ & 39.4 & $15^{\#}$ & 21.1 \\
\hline Olympic aerobic athletes & 33 & $13^{\delta^{*}}$ & 39.4 & $10^{\S^{*}}$ & 30.3 & $10^{\S^{*}}$ & 30.3 \\
\hline Road cyclists & 10 & 4 & 40.0 & 4 & 40.0 & 2 & 20.0 \\
\hline Track and field runners & 7 & 2 & 28.6 & 2 & 28.6 & 3 & 42.8 \\
\hline Cross-country skiers & 16 & 7 & 43.7 & 4 & 25.0 & 5 & 31.3 \\
\hline Anaerobic athletes & $n$ & $n$ & $\%$ & $n$ & $\%$ & $n$ & $\%$ \\
\hline All flat-water kayakers & 55 & $21^{\#}$ & 38.2 & $31^{\#}$ & 56.4 & $3^{\#}$ & 5.5 \\
\hline Olympic flat-water kayakers & 19 & $7^{*}$ & 36.8 & $11^{*}$ & 57.9 & $1^{*}$ & 5.3 \\
\hline Healthy population & $n$ & $n$ & $\%$ & $n$ & $\%$ & $n$ & $\%$ \\
\hline & 152 & $67^{\S}$ & 44.1 & $66^{\S}$ & 43.4 & $19^{\S}$ & 12.5 \\
\hline
\end{tabular}

The I/D ACE gene polymorphism was investigated as described ${ }^{2}$ and confirmed by means of a second PCR amplification that selectively detects the I allele. ${ }^{14} \mathrm{DD}$, homozygotes for the deletion allele; II, homozygotes for the insertion allele; ID, heterozygotes. \# $\chi^{2}=7.238$, exact $P=0.03$ for genotype frequencies in all kayakers $v s$ all aerobic athletes. $\delta \chi^{2}=6.755$, exact $P=0.03$ for genotype frequencies in aerobic Olympic athletes $v s$ healthy population. ${ }^{*} \chi^{2}=5.867$, exact $P=0.05$ for genotype frequencies in Olympic kayakers $v s$ Olympic aerobic athletes. 
genotypes. The II genotype was more frequent in the 33 Olympic aerobic athletes than in the 19 Olympic anaerobic athletes (Table 1). In addiction, the genotype distribution in the aerobic group differed significantly from that of controls, whose distribution was very similar to that observed in 1307 normal Italian subjects. ${ }^{12}$

These findings, obtained by selecting subjects with top endurance characteristics, confirm the association of the II genotype with improved aerobic performance, and extend the results of Nazarov et al. ${ }^{11}$ to long distance athletes.

Although it has been suggested that the higher ACE II genotype frequency in endurance athletes could reflect the selection of individuals with a 'healthier' cardiovascular system and improved aerobic capacity, ${ }^{9}$ a physiological explanation for the association between ACE genotype and endurance phenotypes is not available at present. ${ }^{9}$ Increased $\mathrm{O}_{2}$ or substrate availability as well as improved mitochondrial metabolism, ${ }^{4,13}$ are plausible candidates to explain the positive selection of this genotype among elite athletes.

Daniela Scanavini ${ }^{1}$, Francesco Bernardi ${ }^{1}$, Elisabetta Castoldi ${ }^{1}$, Francesco Conconi ${ }^{2}$ and Gianni Mazzoni ${ }^{2}$

${ }^{1}$ Dipartimento di Biochimica e Biologia Molecolare, Università di Ferrara, via L. Borsari 46, 44100 Ferrara, Italia

${ }^{2}$ Centro di Studi Biomedici Applicati allo Sport, Università di Ferrara, via Gramicia 35, 44100 Ferrara, Italia

\section{References}

1 Kem DC, Brown RD: Renin - from beginning to end. N Engl J Med 1990; 323: 1136-1137.
2 Rigat B, Hubert C, Alhenc-Gelas F, Cambien F, Corvol P, Soubrier F: An insertion/deletion polymorphism in the angiotensin Iconverting enzyme gene accounting for half the variance of serum enzyme levels. J Clin Invest 1990; 86: 1343-1346.

3 Danser AH, Schalekamp MA, Bax WA et al: Angiotensin converting enzyme in the human heart: effect of the deletion/insertion polymorphism. Circulation 1995; 92: 1387-1388.

4 Montgomery HE, Marshall R, Hemingway $\mathrm{H}$ et al: Human gene for physical performance. Nature 1998; 393: 221-222.

5 Gayagay G, Yu B, Hambly B et al: Elite endurance athletes and the ACE I allele: the role of genes in athletic performance. Hum Genet 1998; 103: 48-50.

6 Myerson S, Hemingway H, Budget R, Martin J, Humphries S, Montgomery H: Human angiotensin I-converting enzyme gene and endurance performance. J Appl Physiol 1999; 87: 1313-1316.

7 Alvarez R, Terrados N, Ortolano R et al: Genetic variation in the renin-angiotensin system and athletic performance. Eur J Appl Physiol 2000; 82: 117-120.

8 Woods D, Hickman M, Jamshidi Y et al: Elite swimmers and the D allele of the ACE I/D polymorphism. Hum Genet 2001; 108: 230232.

9 Rankinen T, Wolfarth B, Simoneau JA et al: No association between the angiotensin-converting enzyme and elite endurance athlete status. J Appl Physiol 2000; 88: 1571-1575.

10 Taylor RR, Mamotte CDS, Fallon K, Bockxmeer FM: Elite athletes and the gene for angiotensin-converting enzyme. J Appl Physiol 1999; 87: 1035 - 1037.

11 Nazarov IB, Woods DR, Montgomery HE et al: The angiotensin converting enzyme I/D polymorphism in Russian athletes. Eur J Hum Genet 2001; 9: 797-801.

12 Aucella F, Vigilante M, Margaglione $\mathrm{M}$ et al: Polymorphism of the angiotensin-converting enzyme gene in end-stage failure patients. Nephron 2000; 85: 54-59.

13 Williams AG, Rayson MP, Jubb M et al: The ACE gene and muscle performance. Nature 2000; 403: 614.

14 Lindpaintner K, Pfeffer MA, Kreutz R et al: A prospective evaluation of an angiotensin-converting-enzyme gene polymorphism and the risk of ischemic heart disease. $N$ Engl J Med 1995; 332: $706-711$. 